\title{
Application of Geographical Information System in Analysis of Suitability Refuse Dump Sites Location of Keffi town, Nasarawa state
}

\author{
I. Sufiyan, M.A. Modibbo, K. K. Geidam \\ Department of Geoinformatics Federal Polytechnic Nasarawa, Nasarawa state \\ Surveying and Geoinformatics Programme Abubakar Tafawa Balewa University Bauchi, Bauchi state \\ Department of General studies Mai Idris Alooma Polytechnic Geidam, Yobe state
}

\begin{abstract}
Most of the developing countries are facing a lot of problems concerning to the garbage disposal and waste management. The truth is that, population is increasing; as such the rate of consumption also increases. These create more issues and problems in relation to social, environment, economic and health especially towards finding the most suitable location for dumping sites. There are cases of outbreak of diseases through water contamination, pollution and unpleasant odor due to the closeness of the disposal sites to residential. This and much more had affected the urban aesthetics that most local authorities have ignored the effects of municipal solid waste disposal. This study aims to verify the suitability of refuse dump site locations and to provide solution to where the new locations of the 10 dump sites will be located. Ten existing refuse dump site locations are considered by using suitability criteria such as roads, rivers, vegetation and residential areas. Various analyses are performed such as the kernel density, Euclidean distance and buffer analysis using spatial analyst in ArcGIS 10.0. The result from GIS analysis had shown that all the present existing ten refuse dump sites in Keffi are not suitable for dumping sites.
\end{abstract}

Key words: Dump site GIS and Solid waste Refuse

\section{Introduction}

It is an important area of emphasis on the provision of environmental qualities to dispose waste properly and if possible to find ways of changing the waste into useful materials. Management of waste, both liquid and solid, has become a critical environmental concern particularly in the urban population of Nigeria. The increase in the rate of consumption and rise in per capita income accelerates the rate of dumping of solid waste. All waste materials, whether they are hazardous or non-hazardous fall within the remit of waste management. Waste management practices can differ for developing and developed countries, for rural and urban area, and for large scale or producers in manufacturing industries. Management of residential and institutional waste in metropolitan areas is usually the responsibility of local authorities, while management for non-hazardous commercial and waste from the industries is usually the responsibility of the generator subject to local, national or international controls (Vesilind et al., 2002; Agamuthu, 1997; Begum et al).

The collection, and ultimate disposition of household and commercial waste, is one of the fundamental local government services, essential to maintaining a clean and disease free society. Urban areas are littered with garbage as a result. To find suitable land for disposal, or central waste treatment plan and management facilities in most of the urban areas become difficult. The problem is most severe in the densely populated areas especially in Nigeria. The increase in resource consumption pattern has had an unintended and negative impact on the urban environment- generation of waste far beyond the capacities of urban government and other agencies. These problems forced the most communities to participate in daily or weekly sanitation or involving private sector into private partnership for the collection of huge refuse dumps. In the view of the above statement, there are so many techniques that have been applied to overcome dumping of waste and of the latest technology to use as a tool is known as Geographic Information System.

The solid wastes are categorized into residential, commercial, municipal, industrial, open Area, treatment plan and Agricultural waste In other word, solid waste can be organic or inorganic waste materials produced by various activities of the club. In order to determine the suitability of refuse dump sites, efficiently and effectively in any Nigerian community, there is need to develop a national waste disposal database. This study would develop a GIS database on refuse disposal and to identify the exact location of the dump sites. The developed system will be utilized in the management and planning for solid waste disposal, which would eventually eliminate and eradicate the problems, associated healthy human conditions (Tchobanoglous, 1993; Bamgbose, 2009). 


\subsection{Municipal Solid Waste}

A municipal solid waste management system needs solid management techniques where the present of a sanitary landfill is important. The versatility of landfills increase in the rate of population growth, and the dump sites also increase in number. This turns the situation very difficult and challenging issue especially GIS to make decisions using multi-criteria analysis to select the optimal dumping sites (Yesilnacar et al., 2012). Solid waste management is a complex process that requires the cooperation of the Local Authorities and the participation of the private partnership and other disciplines. In this juncture, the use of technology, and many innovative solutions is greatly paramount in association with the disposal, generation, handling, storage, collection, transfer, transportation, processing and recycling of waste have been advanced to address this problem. All of these processes perhaps innovative or classical have followed the existing legal regulatory and social guidelines that protect the public health and the environment. For the disposal process to be responsive to the public attitudes the disciples that must be considered in administration, financial, legal, architectural, planning and engineering functions must be incorporated. On July 1970, management Information System Development was created for information on solid waste in the U.S. A solid waste basic data network was initiated by the U.S to provide from sample which can protect the environment on the issue of waste disposal. Standardized and reliable data on solid waste characteristics, waste generation rate, system and subsystem operations and solid waste handling cost were sufficient.

The pattern of household waste cannot be understood independently of the broader practice of municipal waste management. Since the recovery of re-usable material from the waste stream can be conceptualized as an alternative to the routine collection and disposal of waste. Within developed economies the emergence of a legislative framework for waste management can be traced to the public health fears associated with rapid industrialization and urbanization in the nineteenth century (Grover, 2000). Until the 1930s, waste management in developed economies was quite straightforward: household rubbish was burnt in a basic incinerator or dumped on an open hip. Industrial wastes were not as numerous or complex as they are now, and were often deposited on a site acquired by the owner of the factory where they originated or disposed of along with household and other waste. Any processes for recovery of certain component of waste will of course, have to be incorporated into a waste treatment system. Separated plants can generally treat only domestic waste. Industrial and bulky waste presents inseparable difficulties owing to their varying composition and dimension.

At the beginning of the 1990s, most municipal refuse is disposed of by tipping at so-called landfill site. However, this option is traced with growing political and economic difficulties land till has been criticized as a viable disposed option because it produces toxic lactates which can contaminate waste supplies and also produces combustible landfill gas from the anaerobic decomposition of putrefied waste. There gases, once they have entered the atmosphere, act as greenhouse agents, and one kilogram of methane is believed to be up to 60 more powerful than carbon dioxide in its contribution to global warming and constitutes some 16 percent of greenhouse gases. Therefore, landfills continue to be the useful center for refuse disposal, depending on the location, about 90 percent of solid waste generated in all over the world is recently disposed in landfills (Gendebien et al., 1992).

Landfilling is probably the cheapest way to treat waste. Therefore, up to $80 \%$ of the world practice open dumping or landfilling. For this reason, special attention should be paid to this final disposal option, mainly in developing countries. In continents such as Africa, $95 \%$ of all social waste is dumped or landfilling (Grover, 2000). Due to the lack of proper collection systems, it is still common for people in developing countries to discard garbage directly onto the street, into canals and on river banks. As soon as dumping starts, the dumping area becomes larger. Waste attracts more waste. When the quantity of waste generated becomes a problem for the surroundings, the waste is set alight. In many cities, the smoke hangs over the roofs with a sweet, sticky smell. Such open burning of dump sites causes health problems by releasing dangerous pollutants in the air. However, the fire and the smoke kill flies and prevent the insect from breeding. In some cities, it is uncertain whether or not collected waste is taken to the city dump. Using waste as filling in construction areas has caused damage to buildings because decomposition, explosive and toxic gases are generated. These gases permeate up into the buildings and represent a risk for residents. The increase in population in most developing countries has made urban planning difficulty. There is no landfill in Chennai city that make it possible to find suitable land for solid waste disposal in India. Mostly the use of fussy logic is applied to such situation (Suresh and Usha, 2008).

\section{Problem Statement}

Problems associated with the undertaking of environmental issues such as refuse dump site locations of in today's society is complex because of the quantity and diverse nature of the wastes being disposed every day. No proper refuse dumps sites locations. Many person disposes refuse recklessly. Vacant lands that are useful for urban development were turned into dumping sites or landfills. The concentration of human settlement has the ability to produce large amount of waste (Zerbock, 2003). How refuse dump sites and planning of waste disposal has affected the development of cities aesthetics, and what are the impacts of the 
dump sites locations at the local level. So far, there is no efficient system to manage the existing refuse dumps in Keffi, Nigeria. Residents in the area are attacked by diseases and unhealthy conditions. Large quantities of waste materials are being disposed and burnt without collection thereby creating pollution and environmental uncertainties. Solid waste has a potential to pollute our environment through the air, land and water at local and global levels. So, we have to find the convenient way to monitor and manage the disposal of waste as compared to the conventional methods of disposal.

The objectives of this study are to: locate the locations of the existing dump sites, identify related issues pertaining to the proximity of the dump site locations, create a GIS database relating to the dump sites and analyze the suitability of the dump site locations using GIS analysis.

\subsection{Study Area}

Keffi is a located at Lat $8^{\circ}, 51^{\prime} 25^{\prime \prime} \mathrm{N}$ and Long $7^{\circ}, 52^{\prime} 40^{\prime \prime} \mathrm{E}$ and it has an area of $13 \mathrm{~km}^{2}$. Historically, Nassarawa State came into existence on the 1st of October, 1996, by the then military government. Figure 1.1 shows Keffi town in within the state.

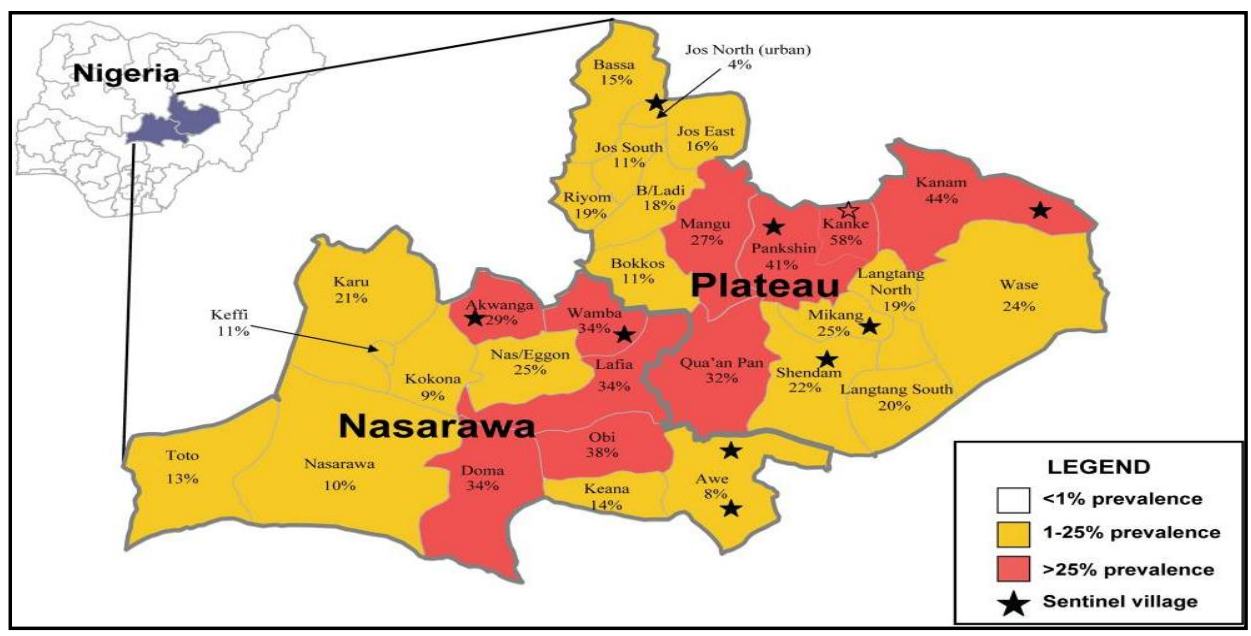

Figure 1.1: Nasarawa state and the study area (source: ajtmh.org)

\subsubsection{Population}

Nassarawa State had a total population of 1,869,377. As at the 2006 census head counts, out it Keffi has about 92,664 inhabitants. Agriculture is the main economic activity in Nassarawa State. There is potentials for numerous tourist and recreational sites to be developed and utilized. The Eggon rolling hills and caves, Ferin Ruwa Falls in Wamba, Hunki Lake in Awe, the famous traditional pottery industry and Malloney Hill in Keffi , the Umaisha festival in TotoNasarawa state was endowed with solid Mineral such as barytes, barytes, sharp sand, tin, marble, salt, coal, semiprecious stones and aqua marine. Its slogan as: "home of Solid Minerals". The conduct of reliable population census in Nigeria is a mirage due to the heterogeneous nature of the states in Nigeria (Bamgbose, 2009). Figure 1.2 shows map of Nigeria, Nasarawa and Keffi.

\section{Methodology}

Data collection is a procedure established to develop and define the required data types and the qualities and quantities of data gathered. The refuse dump site data are collected and georeferenced as a spatial data. The non-spatial data include the types of refuse disposed, number of households, number of people in a household, the weight of the waste disposed, are all required for developing the database. Figure 3.1 illustrates the flow chart used in this study, whereas Figure 3.2 shows the model builder of the project. 


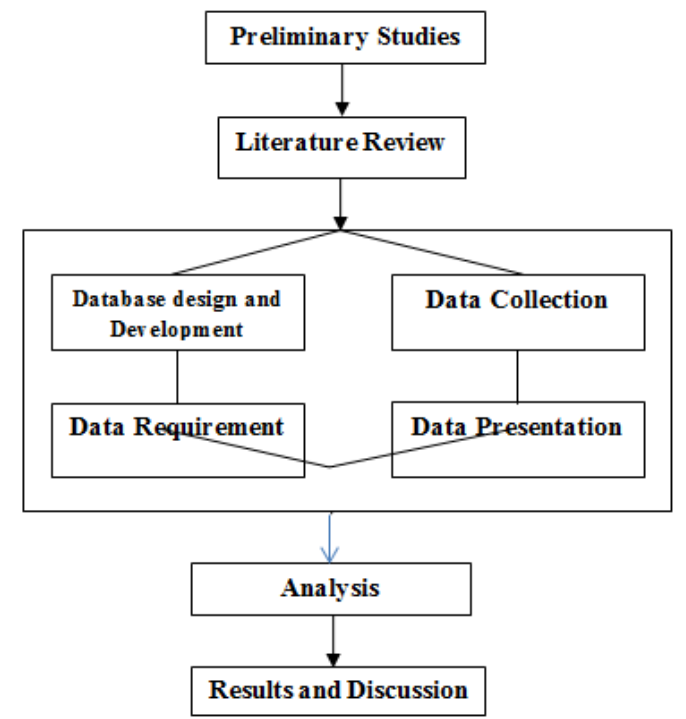

Figure 3.1: Flowchart methodology used in this study

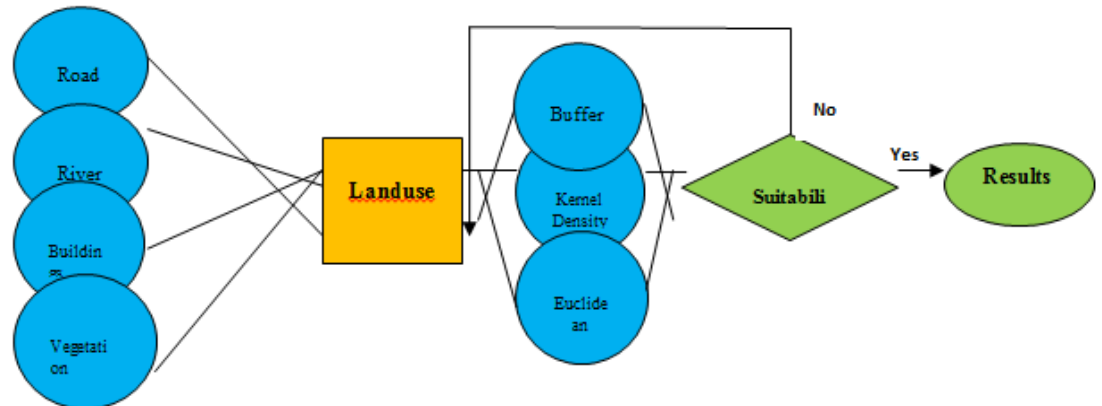

Figure 3.2: The model builder of the Project

\subsection{Required Data Types for This Study}

The data collection process involved the use of the following GIS input;

a) Scanned map (roads, buildings, rivers and vegetation)

b) Dumps sites location (GPS)

c) Digitized map of the study area

d) Questionnaires (URA)

e) Satellite imageries (Georeferenced map and digitized layers)

f) Photograph (Dump Sites Locations)

\subsection{Data Collection}

The field data of the 10 refuse dumps are of two types; that is primary and secondary data as shown in Table 3.1. About 10 selected dump sites were chosen from the study area with their accurate coordinates. It is paramount to consider the dump site locations, as distributed over the space, by this we can visualize its problems with the environment as well as design appropriate analyses for all the refuse dump sites. While for the attribute data, we used the database and some statistical techniques. Careful planning and design, using the required analyses for the dump sites is important so that residential disposal have been monitored.

Table 3.1: Data used in this study

\begin{tabular}{|c|l|l|}
\hline Data Type & \multicolumn{1}{|c|}{ Data } & \multicolumn{1}{|c|}{ Source } \\
\hline Primary & From candidates Questionnaire & People around Keffi \\
\hline Secondary & $\begin{array}{l}\text { Vector: Road, River, Building, Vegetation, } \\
\text { refuse dump location, and candidates }\end{array}$ & $\begin{array}{l}\text { Digitizing and visualisation from Google earth } \\
\text { and geocode and georefrencing from address } \\
\text { and questioner }\end{array}$ \\
\cline { 2 - 3 } & $\begin{array}{l}\text { Raster: } \\
\text { 1) Google Earth Image } \\
\text { 2) Photograph of the refuse dump locations }\end{array}$ & Georefrencing by taking GCP at Google earth \\
\hline
\end{tabular}




\subsubsection{Primary and Secondary source of data}

The primary source, involved the use of User Requirement Analysis (URA) by establishing and administering questionnaires. About 55 questionnaire sample was surveyed in the field for this study. The secondary data involved use of existing map of the Nasarawa State, Keffi Local Government Authority (vector and raster data) and the photographs of the selected refuse dump sites. Figure 3.3 shows the refuse disposed rampantly on the road and riverside.

\subsubsection{Software}

Software used in this study is ArcGIS 10, for data processing, creating database and analysis, and lastly for the analysis of the final results.

\subsection{Hardware}

This includes computer, and Operating System such as Window, monitor for display, scanner, digitizer, GPS receivers, printer, and many more all are used in present study.

\subsection{Method of Research}

The method of the research in this study is quantitative in nature. In the early stage of this study, understanding on overall of research is important to ensure the needs requirement, problems, objectives, aim, and data collecting. Based on this study, we utilize the GIS applications to solve the problems of dump site locations in Keffi Nigeria.

\subsubsection{Data Preparation}

This study contributes of high and huge datasets in term of accuracy, storage, and others. A variety of methods used for collecting data likes, interview in Keffi local government health care department and zonal inspectorate. Private organizations such as the private partnership participation NGOs all in Keffi and in order to gather the data, much more information related to this study was conducted.

\subsubsection{Spatial Analysis}

Spatial analysis in this study was conducted using GIS which has the capabilities on handling spatial data especially geographical data. In this study,

The Figure 3.3 is an example of GIS capabilities.

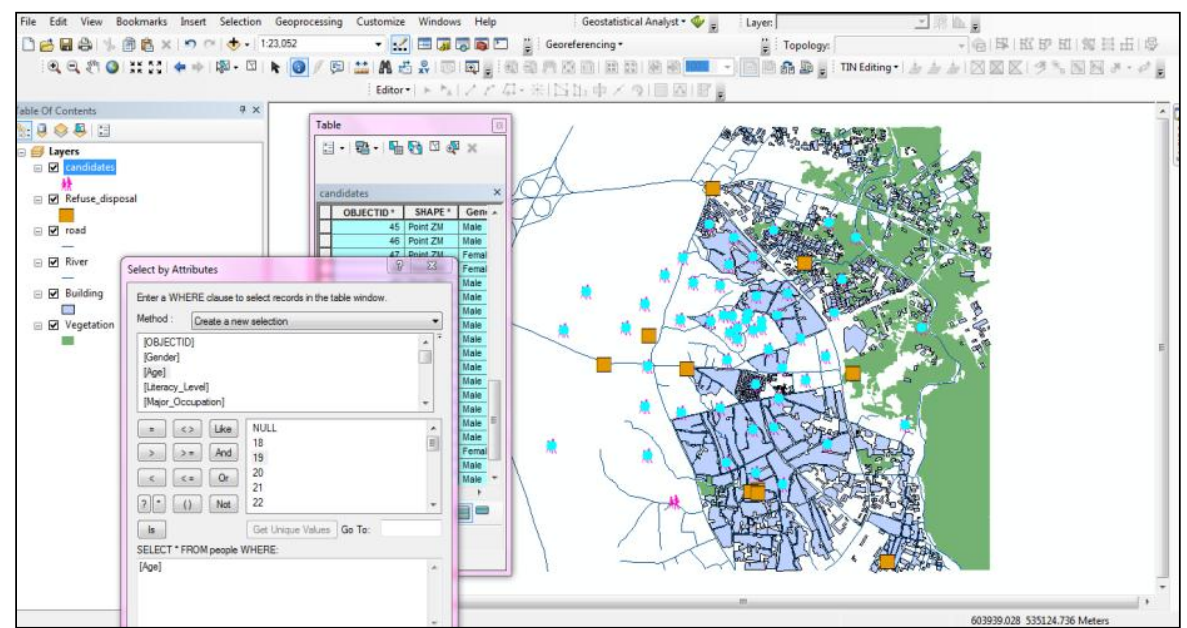

ArcGIS 10 is used to conduct the spatial analysis likes, clipping, Euclidean distance, kernel density, intersecting and buffering to produce the outcome or results in form map and other output. The developmental data are important in providing spatial and non-spatial. It both displays the output and relate to what can be done especially in decision making.

\subsubsection{Database Development}

A database is a medium for storing and managing the spatial data and its attributes. This is important in developing a geographic information system. Generally, before capturing the answers, we must do data collecting first and store it to make it manageable. The database has high capabilities to store and secure the data organize well. The purpose to acquire a database is for ensuring the information is not redundantly and as a 
result the storage required is less. In this study, there are 3 types of database designs, which are conceptual, logical and physical designs. Figure 3.5 illustrates the flow chart of the database development process.

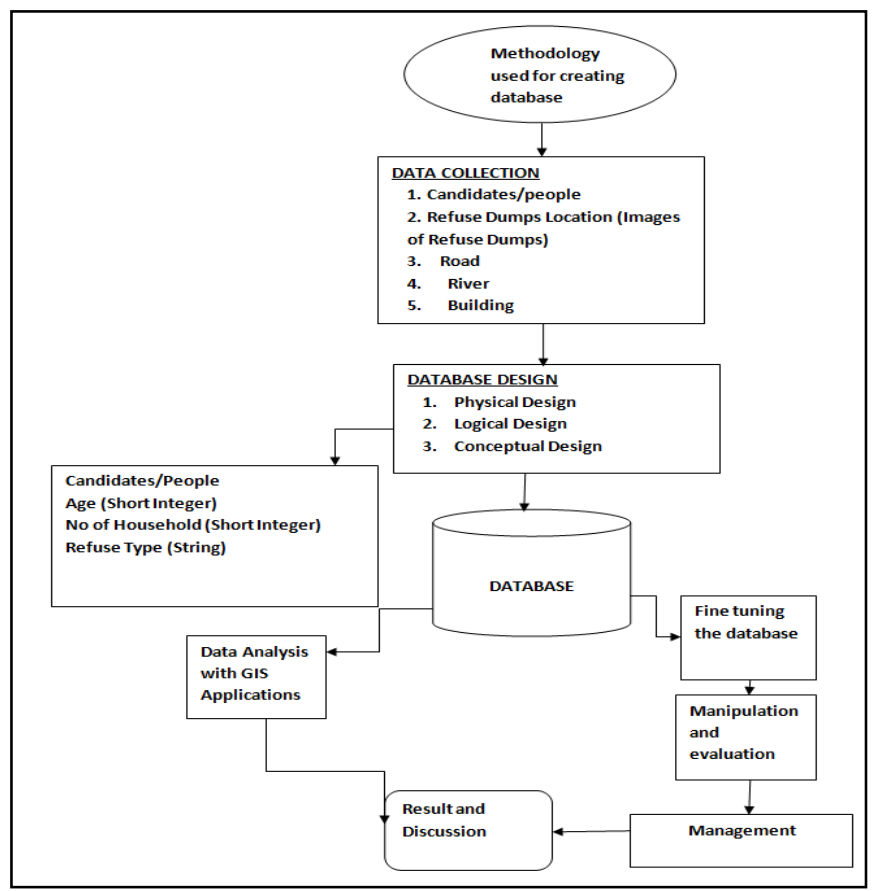

3.4Databasedevelopment processes

Table 3.2: Data types as stored in Database

\begin{tabular}{|l|l|l|l|}
\hline Entity Name & Attributes & Description & Data Type \\
\hline Road & $\begin{array}{l}\text { ID } \\
\text { Length } \\
\text { Type }\end{array}$ & Layer contains the major and minor road & $\begin{array}{l}\text { Object id } \\
\text { Double } \\
\text { Text (string) }\end{array}$ \\
\hline River & $\begin{array}{l}\text { Id } \\
\text { Length }\end{array}$ & Show the length of the river & $\begin{array}{l}\text { Object id } \\
\text { Double }\end{array}$ \\
\hline People/candidates & $\begin{array}{l}\text { Id } \\
\text { Name } \\
\text { Age } \\
\text { Gender }\end{array}$ & $\begin{array}{l}\text { Based on geocode the address of the } \\
\text { questionnaire }\end{array}$ & $\begin{array}{l}\text { Object id } \\
\text { String } \\
\text { Short Integer } \\
\text { String }\end{array}$ \\
\hline Refuse dump site & $\begin{array}{l}\text { Id } \\
\text { Name } \\
\text { Raster }\end{array}$ & $\begin{array}{l}\text { Field identification (snap image) and } \\
\text { visualization of the Google earth image } \\
\text { for location }\end{array}$ & $\begin{array}{l}\text { Object id } \\
\text { String }\end{array}$ \\
\hline Vegetation & $\begin{array}{l}\text { Id } \\
\text { Type } \\
\text { Area }\end{array}$ & $\begin{array}{l}\text { The type and location of vegetation in } \\
\text { the area at Keffi }\end{array}$ & $\begin{array}{l}\text { Object id } \\
\text { String } \\
\text { Double }\end{array}$ \\
\hline Building & $\begin{array}{l}\text { Id } \\
\text { Type }\end{array}$ & $\begin{array}{l}\text { Contain the residential area, hospital, } \\
\text { mosque and its }\end{array}$ & $\begin{array}{l}\text { Object id } \\
\text { String }\end{array}$ \\
\hline
\end{tabular}

\subsubsection{Physical Design}

Physical design refers to the implementation of the database to secondary memory and explains the structure of storage, data access method, in order to achieve effective data and communicate it directly with the Database Management System (DBMS) that will be used.

\subsubsection{Data Requirements}

Developing database is to create the structured data storage systems that simplify the process of accessing towards the data and support the study. Based on Figure 3.7, the database was developed by using ArcGIS 10 "ArcCatalog". It can be determined from the resulting database is arranged in a personal geodatabase and divided according to Dataset Features categories such as Land Use, Topography, raster as well as digital elevation model. The model followed by personal geodatabase then feature datasets and lastly is feature class. 


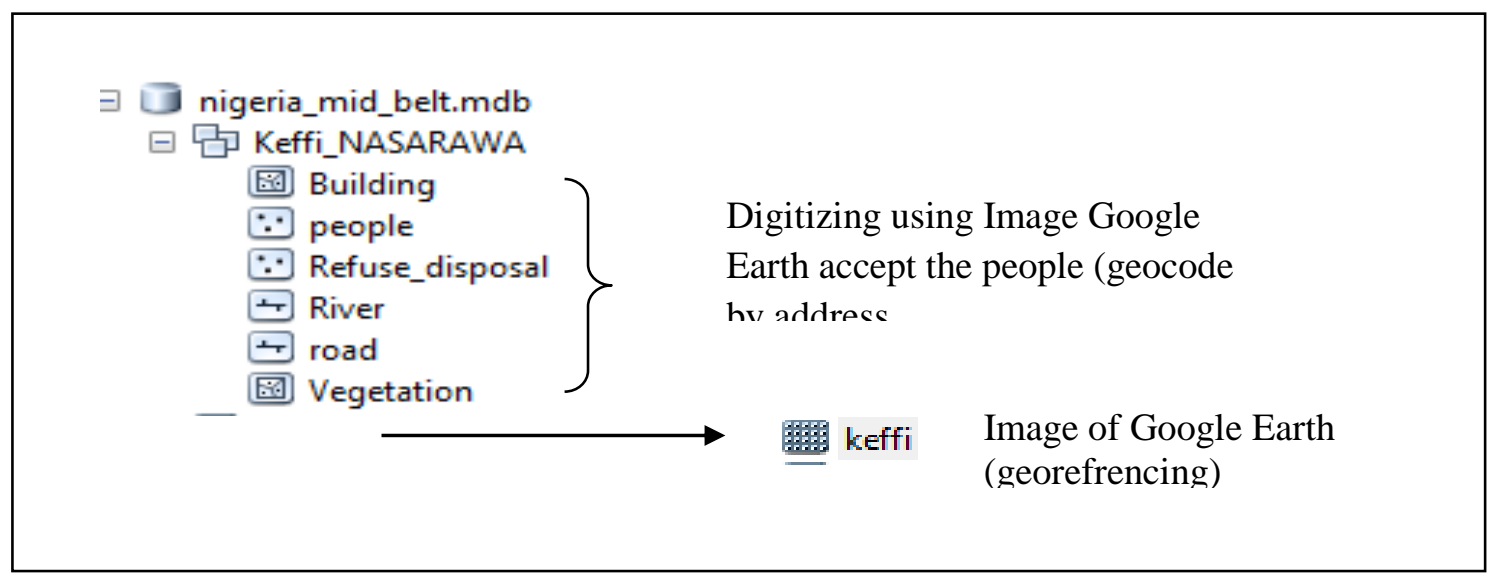

Figure 3.5: Structure design of Geodatabase

\subsubsection{Data Processing}

The data obtained was stored in a DBMS and should be revised according to various criteria such as data type, coordinate reference systems, scale, topology, and other attributes. The information received in digital form is reviewed to assure that no errors, redundancy or duplication occurs.

\section{Analysis of Results}

Under this an analysis of the field data collected was discussed and the results were also being provided.

\subsection{Analysis of Existing Refuse Dump Sites Locations in Keffi}

From the Figure 4.1, we can see that almost all 10 refuse dump sites is close to the vegetation area, residential area, river area, and the road. The Table 4.1 and 4.2 issues presented with statistics as answered by the candidates on the questionnaires. Tables 4.2 and 4.3 are shown the statistical analysis using SPSS by calculating mean, media and standard deviation from the household population.

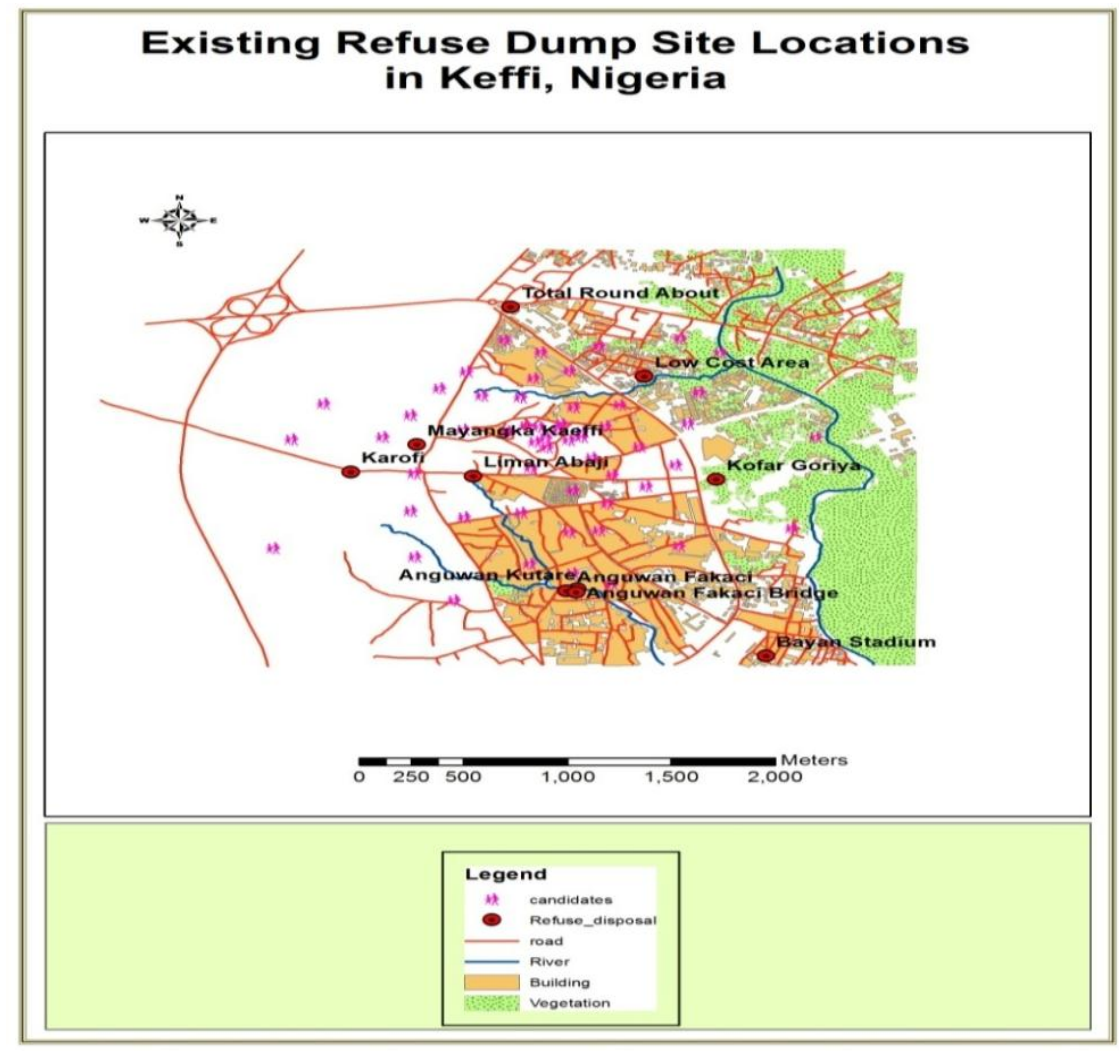

Figure4.1: Present existing refuse dump site locations in Keffi 
Table 4.1: Statistics analysis from the questionnaire

\begin{tabular}{|c|c|c|c|c|c|c|c|c|c|}
\hline & & & & & & & & \multicolumn{2}{|c|}{ Statistics } \\
\hline & & GENDER & AGE & $\begin{array}{l}\text { LITERACY } \\
\text { LEVEL }\end{array}$ & $\begin{array}{l}\text { MAJOR } \\
\text { OCCUPATI } \\
\text { ON }\end{array}$ & $\begin{array}{l}\text { HOUSEHOLD } \\
\text { SIZE }\end{array}$ & $\begin{array}{c}\text { REFUSE } \\
\text { DISPOS- } \\
\text { AL } \\
\text { TYPE }\end{array}$ & $\begin{array}{l}\text { HOW } \\
\text { REFUSE } \\
\text { ARE } \\
\text { GENERAT- } \\
\text { ED }\end{array}$ & $\begin{array}{l}\text { TYPES OF } \\
\text { REFUSE } \\
\text { DISPOSED }\end{array}$ \\
\hline \multirow[t]{2}{*}{$\mathrm{N}$} & Valid & 55 & 55 & 55 & 55 & 55 & 55 & 55 & 55 \\
\hline & Missing & 0 & 0 & 0 & 0 & 0 & 0 & 0 & 0 \\
\hline \multicolumn{2}{|l|}{ Mean } & 1.20 & 1.58 & 2.98 & 1.75 & 2.25 & 1.55 & 1.85 & 2.75 \\
\hline \multirow{2}{*}{\multicolumn{2}{|c|}{ Median }} & 1.00 & 1.00 & 3.00 & 2.00 & 2.00 & 1.00 & 2.00 & 3.00 \\
\hline Mode & & 1 & 1 & 3 & 2 & 2 & 1 & 2 & 2 \\
\hline \multicolumn{2}{|c|}{ Std. Deviation } & .404 & .762 & .490 & .726 & 1.265 & .603 & .591 & 1.308 \\
\hline \multicolumn{2}{|l|}{ Skexpness. } & 1.542 & 1.405 & 1.909 & 1.942 & 1.035 & .608 & .036 & .545 \\
\hline \multicolumn{2}{|c|}{ Std. Error of Skexxness } & .322 & .322 & .322 & .322 & .322 & .322 & .322 & .322 \\
\hline \multicolumn{2}{|c|}{ Sum } & 66 & 87 & 164 & 96 & 124 & 85 & 102 & 151 \\
\hline \multirow{3}{*}{$\begin{array}{l}\text { Percentile } \\
\text { s }\end{array}$} & 25 & 1.00 & 1.00 & 3.00 & 1.00 & 1.00 & 1.00 & 1.00 & 2.00 \\
\hline & 50 & 1.00 & 1.00 & 3.00 & 2.00 & 2.00 & 1.00 & 2.00 & 3.00 \\
\hline & 75 & 1.00 & 2.00 & 3.00 & 2.00 & 3.00 & 2.00 & 2.00 & 3.00 \\
\hline
\end{tabular}

Table 4.2: Statistics analysis from the questionnaire

\begin{tabular}{|c|c|c|c|c|c|c|c|c|c|}
\hline & & \multicolumn{8}{|c|}{ Statistics } \\
\hline & & $\begin{array}{l}\text { MATERIAL } \\
\text { SELECTION } \\
\text { FROM } \\
\text { REFUSE } \\
\text { BEFORE } \\
\text { DISPOSAL }\end{array}$ & $\begin{array}{c}\text { METHODS } \\
\text { OF } \\
\text { REFUSE } \\
\text { DISPOSAL }\end{array}$ & $\begin{array}{c}\text { WEIGHT } \\
\text { OF } \\
\text { REFUSE } \\
\text { DISPOSED } \\
\text { PER WEEK }\end{array}$ & $\begin{array}{c}\text { IS } \\
\text { RECYCLING } \\
\text { GOOD? }\end{array}$ & $\begin{array}{c}\text { FREQUE } \\
\text { NCY OF } \\
\text { REFUSE } \\
\text { DISPOSA } \\
\text { L/GENER } \\
\text { ATION }\end{array}$ & $\begin{array}{c}\text { FREQUEN- } \\
\text { CY OF } \\
\text { SANITATI- } \\
\text { ON }\end{array}$ & $\begin{array}{c}\text { USE OF } \\
\text { G.I.S IN } \\
\text { RECYCLI } \\
\text { NG }\end{array}$ & $\begin{array}{c}\text { REFUSE } \\
\text { DISPOSAL } \\
\text { MANAGE } \\
\text { MENT } \\
\text { TYPE }\end{array}$ \\
\hline \multirow[t]{2}{*}{ N } & Valid & 55 & 55 & 55 & 55 & 55 & 55 & 55 & 55 \\
\hline & Missing & 0 & 0 & 0 & 0 & 0 & 0 & 0 & 0 \\
\hline \multicolumn{2}{|l|}{ Mean } & 1.76 & 2.80 & 1.89 & 1.15 & 1.27 & 2.53 & 2.89 & 1.85 \\
\hline \multicolumn{2}{|l|}{ Median } & 2.00 & 4.00 & 2.00 & 1.00 & 1.00 & 3.00 & 3.00 & 2.00 \\
\hline \multicolumn{2}{|l|}{ Mode } & 2 & 4 & 1 & 1 & 1 & 3 & 3 & 2 \\
\hline \multicolumn{2}{|c|}{ Std. Deviation } & .637 & 1.393 & .832 & .448 & .449 & .742 & .762 & .405 \\
\hline \multicolumn{2}{|l|}{ Skavness } & .243 & -.353 & .411 & 3.228 & 1.049 & -.945 & -.333 & -1.154 \\
\hline \multicolumn{2}{|c|}{ Std. Error of Skerxness } & .322 & .322 & .322 & .322 & .322 & .322 & .322 & .322 \\
\hline \multicolumn{2}{|l|}{ Sum } & 97 & 154 & 104 & 63 & 70 & 139 & 159 & 102 \\
\hline \multirow{3}{*}{$\begin{array}{l}\text { Percentile } \\
\text { s }\end{array}$} & 25 & 1.00 & 1.00 & 1.00 & 1.00 & 1.00 & 2.00 & 2.00 & 2.00 \\
\hline & 50 & 2.00 & 4.00 & 2.00 & 1.00 & 1.00 & 3.00 & 3.00 & 2.00 \\
\hline & 75 & 2.00 & 4.00 & 3.00 & 1.00 & 2.00 & 3.00 & 3.00 & 2.00 \\
\hline
\end{tabular}

\subsection{Analysis using the Households Population}

In the family, population size is used here to calculate the weight of food waste from each household within the study area in Keffi. The Table 4.3 describes the percentages of people or family size that disposes refuse in the dump sites. As it can be seen from the table, about 22 respondents out of 55 have a family size ranging from 6 to 10 people in a house with $40 \%$ followed by $1-5$ to $30.9 \%, 11-15$ to $12.7 \%, 16-20$ to $5.5 \%$, and households with family size above 21 people has $10.9 \%$ respectively.

Table 4.3: Percentages of household sizes

\begin{tabular}{|c|c|c|c|c|c|}
\hline \multicolumn{6}{|c|}{ HOUSEHOLD SIZE } \\
\hline & Range & Frequency & Percent & Valid Percent & Cumulative Percent \\
\hline \multirow{6}{*}{ Valid } & $1-5$ & 17 & 30.9 & 30.9 & 30.9 \\
\hline & $6-10$ & 22 & 40.0 & 40.0 & 70.9 \\
\hline & $11-15$ & 7 & 12.7 & 12.7 & 83.6 \\
\hline & $16-20$ & 3 & 5.5 & 5.5 & 89.1 \\
\hline & $21 \mathrm{ABOVE}$ & 6 & 10.9 & 10.9 & 100.0 \\
\hline & Total & 55 & 100.0 & 100.0 & \\
\hline
\end{tabular}

The graphical presentation of household size in Keffi with the highest value of $40 \%$, and lowest with $6 \%$. Figure 4.2 shows that 22 repondence have agreed that the their dependence ranges between $6-10$ per households, 1-5 persons with 17 respodence, 11,15 persons with 7 respondence, $16-20$ persons with 3 respondence and above 21 persons with only 6 respondence. 
Figure 4.3 illustrate the bar graph with 22 number of respondents is the highest that agreed the high number of family contributed in disposing refuse in the dump sites with $40 \%$ and the lowest is 3 respondents with only $6 \%$.

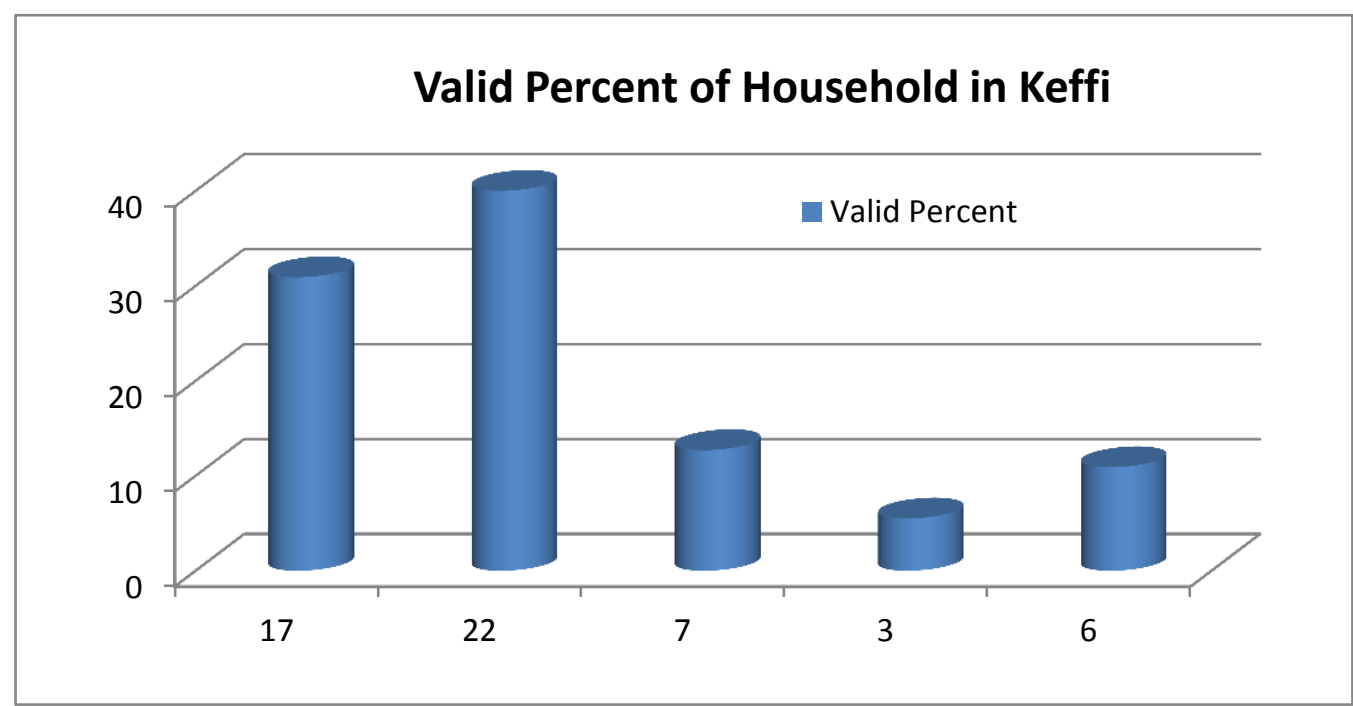

Figure 4.3: The bar graph representing family size per household

Table 4.4 decribes the frequency of refuse disposal in Keffi, with 40 respondent said that they are disposing refuse in the dump site with about $72.7 \%$ while those that disposed refuse weekly in the dump sites are 15 respondents with total of $27.3 \%$ respectively.

Table 4.4: Frequency of refuse disposal

\begin{tabular}{|c|c|c|c|c|c|}
\hline \multicolumn{6}{|c|}{ FREQUENCY OF REFUSE DISPOSAL IN KEFFI } \\
\hline \multirow{3}{*}{ Range } & Frequency & Percent & $\begin{array}{c}\text { Valid } \\
\text { Percent }\end{array}$ & Cumulative Percent \\
\hline \multirow{3}{*}{ Valid } & DAILY & 40 & 72.7 & 72.7 & 72.7 \\
\cline { 2 - 7 } & WEEKLY & 15 & 27.3 & 27.3 & 100 \\
\cline { 2 - 6 } & Total & 55 & 100 & 100 & \\
\hline
\end{tabular}

The graphical presentation with the daily and weekly refuse disposal, daily people disposed refuse with $73 \%$ while $27 \%$ disposes weekly. From this chart we can see that refuse disposal in Keffi is a daily affair with the heighest percentage being disposed daily. Figure 4.4 illustrates that people mostly disposed waste on daily basis in Keffi.

The rapid disposal of refuse in Keffi as decribed by the Table 4.5 has been analyzed about 50 gm weight of refuse is being disposed per week with $38.2 \%$ and those that disposed $1 \mathrm{~kg}$ to $4 \mathrm{~kg}$ has $36.4 \%$. And then about $23.6 \%$ disposed upto $5 \mathrm{~kg}$ daily. Only $1.8 \%$ have no response.

Table 4.5: Weight of weekly refuse disposal in Keffi

\begin{tabular}{|c|c|c|c|c|c|}
\hline \multicolumn{5}{|c|}{ WEIGHT OF REFUSE DISPOSED PER WEEK } \\
\hline \multirow{4}{*}{ Valid } & Range & Frequency & Percent & $\begin{array}{c}\text { Valid } \\
\text { Percent }\end{array}$ & $\begin{array}{c}\text { Cumulative } \\
\text { Percent }\end{array}$ \\
\hline \multirow{4}{*}{$*$} & $50 \mathrm{~g}$ & 21 & 38.2 & 38.2 & 38.2 \\
\cline { 2 - 7 } & $1 \mathrm{~kg}-4 \mathrm{~kg}$ & 20 & 36.4 & 36.4 & 74.5 \\
\cline { 2 - 7 } & $5 \mathrm{~kg}-$ above & 13 & 23.6 & 23.6 & 98.2 \\
\cline { 2 - 7 } & NO RESPONSE & 1 & 1.8 & 1.8 & 100 \\
\hline
\end{tabular}

The Figure 4.5 shows that people mostly disposed refuse which weighted 50 gm per person per week, this perhap is due to the nature of the study area, it is not industrial area where manufacturing is taking place, but most of the refuse generated is commercially and residentail solid wastes. 
The Table 4.6 decribed the varouis method used in disposing refuse, most of the method employed in the study area is taking the waste to refuse dump site with $49.1 \%$, followed by burning with $32.7 \%$, then recycling with $9.1 \%$ and $7.3 \%$ of the waste disposed is burried.

Table 4.6: Different methods of refuse disposal in Keffi

\begin{tabular}{|c|c|c|c|c|c|}
\hline \multirow{4}{*}{ Range } & Frequency & Percent & Valid Percent & $\begin{array}{c}\text { Cumulative } \\
\text { Percent }\end{array}$ \\
\hline \multirow{4}{*}{ Valid } & BURNING & 18 & 32.7 & 32.7 & 32.7 \\
\cline { 2 - 6 } & BURYING & 4 & 7.3 & 7.3 & 40 \\
\cline { 2 - 6 } & RECYCLING & 5 & 9.1 & 9.1 & 49.1 \\
\cline { 2 - 6 } & REFUSE DUMP & 27 & 49.1 & 49.1 & 98.2 \\
\cline { 2 - 6 } & NO RESPONSE & 1 & 1.8 & 1.8 & 100 \\
\hline
\end{tabular}

From the illutration in Figure 4.6 it can be estimated that the highest method adopted by people of Keffi, most of their waste are taking direct to refuse dump and that is more reason why all the refuse dump site are filled-up with greater impacts on environment, socially, economically and health wise.

The next analysis is the types of refuse being disposed, if we look at the compsition of solid waste disposal in developing countries it look similar to these diplayed on the Table 4.7 The highest percent of refuse type being disposed is polythene or plastic bags with $32.7 \%$, followed by garbage with $29.1 \%$, papers with $16.4 \%$, and other refuse constitute $18.2 \%$.

Table 4.7: Types of refuse disposed in Keffi

\begin{tabular}{|c|c|c|c|c|c|}
\hline \multirow{5}{*}{ Range } & Frequency & Percent & $\begin{array}{c}\text { Valid } \\
\text { Percent }\end{array}$ & $\begin{array}{c}\text { Cumulative } \\
\text { Percent }\end{array}$ \\
\hline \multirow{4}{*}{ Valid } & PAPERS & 9 & 16.4 & 16.4 & 16.4 \\
\cline { 2 - 6 } & POLYTHENE & 18 & 32.7 & 32.7 & 49.1 \\
\cline { 2 - 6 } & GARBAGE & 16 & 29.1 & 29.1 & 78.2 \\
\cline { 2 - 6 } & RUBBER & 2 & 3.6 & 3.6 & 81.8 \\
\cline { 2 - 6 } & OTHERS & 10 & 18.2 & 18.2 & 100 \\
\hline
\end{tabular}

The analysis had shown that most of the disposed refuse types consists of polythenes and garbages as displayed graphically in the Figure 4.7.

Most of the refuse generated in Keffi are rise by the family with $63.6 \%$, if we compare it with the people in the household, the single generation is individual with $25.5 \%$ and followed by the neighborhood with $10.9 \%$ as shown in Table 4.8 .

Table 4.8: Generation of refuse in Keffi

\begin{tabular}{|c|c|c|c|c|c|}
\hline \multicolumn{6}{|c|}{ HOW REFUSE ARE GENERATED } \\
\hline & Range & Frequency & Percent & $\begin{array}{l}\text { Valid } \\
\text { Percent }\end{array}$ & $\begin{array}{c}\text { Cumulative } \\
\text { Percent }\end{array}$ \\
\hline \multirow{4}{*}{ Valid } & ALONE & 14 & 25.5 & 25.5 & 25.5 \\
\hline & FAMILY & 35 & 63.6 & 63.6 & 89.1 \\
\hline & NEIGHBORHOOD & 6 & 10.9 & 10.9 & 100 \\
\hline & Total & 55 & 100 & 100 & \\
\hline
\end{tabular}

\subsection{Analysis of Results from the Developed Database}

The rest of the analysis is done using GIS applications. The objectives for this study is to find the result in identifying the dump sites, database, new suitable dump site locations and the issues related to existing dump site location.

\subsubsection{Density of Refuse Dumps}

A kernel density surface, showing the number of refuse dumps per unit area as illustrated in Figure 4.10, this was done using the density toolbox. Kernel density calculates the magnitude per unit area from point features using a kernel function to fit a smoothly tapered surface to each point. The surface value is highest at 
the location of the point and decreases with increasing distance from the point, reaching zero at a search radius distance from the point. A radius of $0.5 \mathrm{~km}$ was used. The extract values to points tool under the extraction toolbox in the spatial analyst extension was used to extract the density values of community centroids and recorded into the attributes of the community feature class.

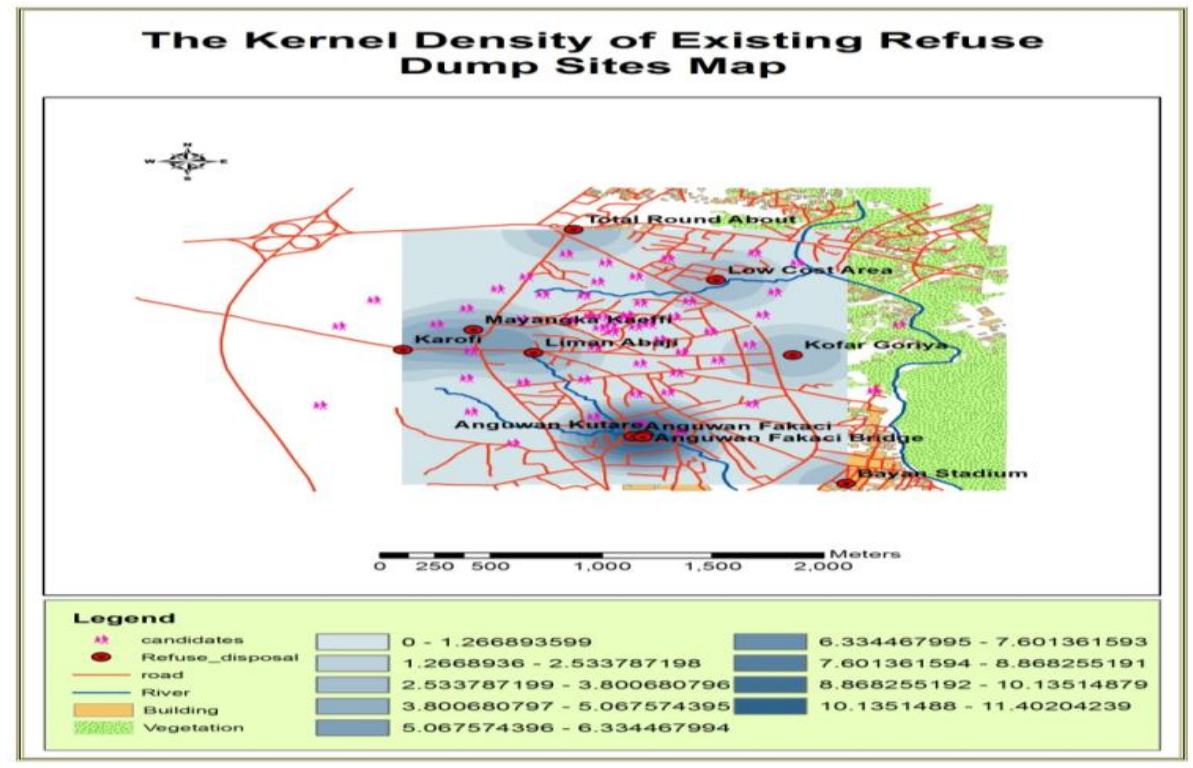

Figure 4.10: Low and high density of the refuse dump site locations

\subsubsection{Proximity to Refuse Dump Sites}

Using Spatial Analyst extension and the Distance toolbox, Euclidean distance surface was generated in ArcMap, with refuse dumps layer selected as input feature source. This calculates for each cell, the Euclidean distance to the closet source. In this study, a search radius of $0.5 \mathrm{~km}$ was used. Figure 4.11 and Table 4.10 shows the approximate distance that affects each landuse.

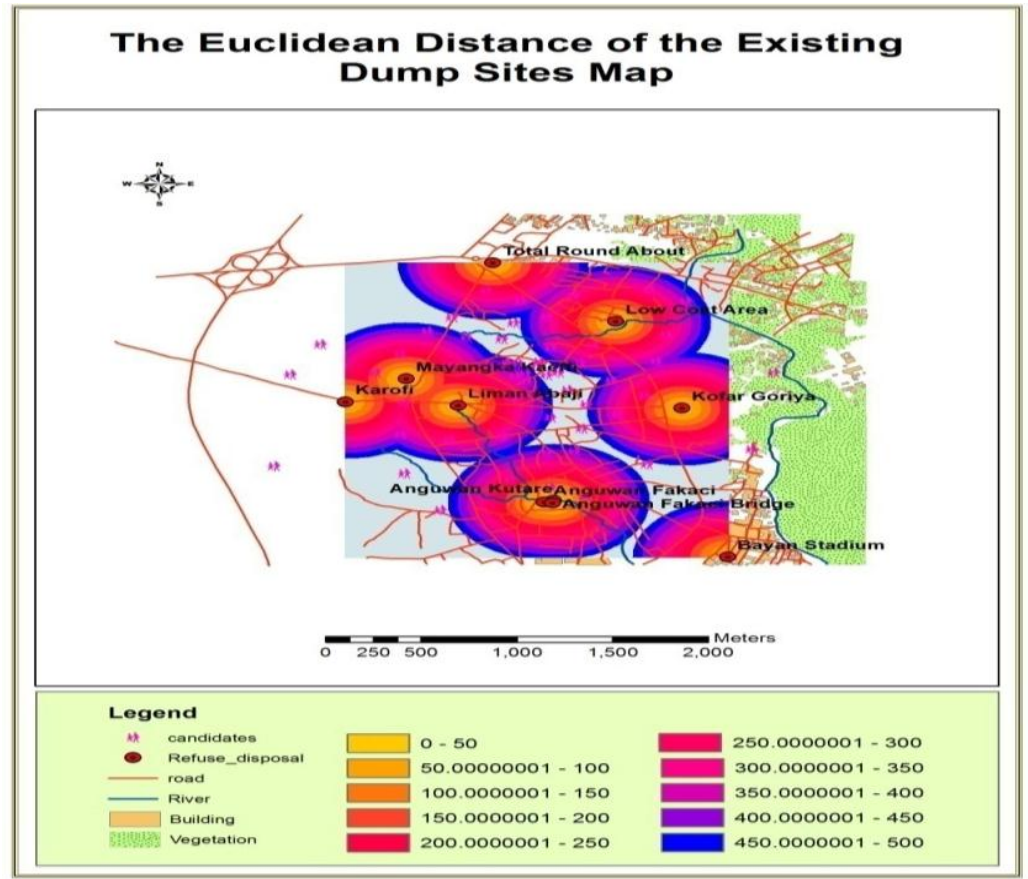

Figure 4.11: Distance of dump sites locations its effects on residential health 
Table 4.10: Distance of the major Landuse in the study area

\begin{tabular}{|l|c|c|c|}
\hline $\begin{array}{l}\text { Type of } \\
\text { Landuse }\end{array}$ & $\begin{array}{c}\text { Total length and area } \\
(\mathbf{m})\end{array}$ & $\begin{array}{c}\text { Location effected } \\
(\mathbf{m})\end{array}$ & $\begin{array}{c}\text { \% location effected (radius } \\
<\mathbf{3 0 0} \mathbf{~ m}>\end{array}$ \\
\hline Road & 71004.02 & 42710.17 & $60 \%$ \\
\hline River & 8483.39 & 4467.01 & $52 \%$ \\
\hline Vegetation & 18709.72 & 4446.59 & $23 \%$ \\
\hline Building & 25334.72 & 20397.48 & $80 \%$ \\
\hline
\end{tabular}

Health issues also it effects the resident due to the distance $(300 \mathrm{~m})$ with highest percentage of $80 \%$. Most of refuse dumps sites are located closed to the river or water resources used for domestic human usage such as drinking, cooking, washing, cleaning, and for and bathing. Examples, the prevalent diseases includes typhoid, cholera, malaria, dysentery, lung cancer and respiratory infections and other related diseases with destruction of ecosystems.

As shown in Figure 4.14 the high probable affected zones are clearly identified using kernel density.

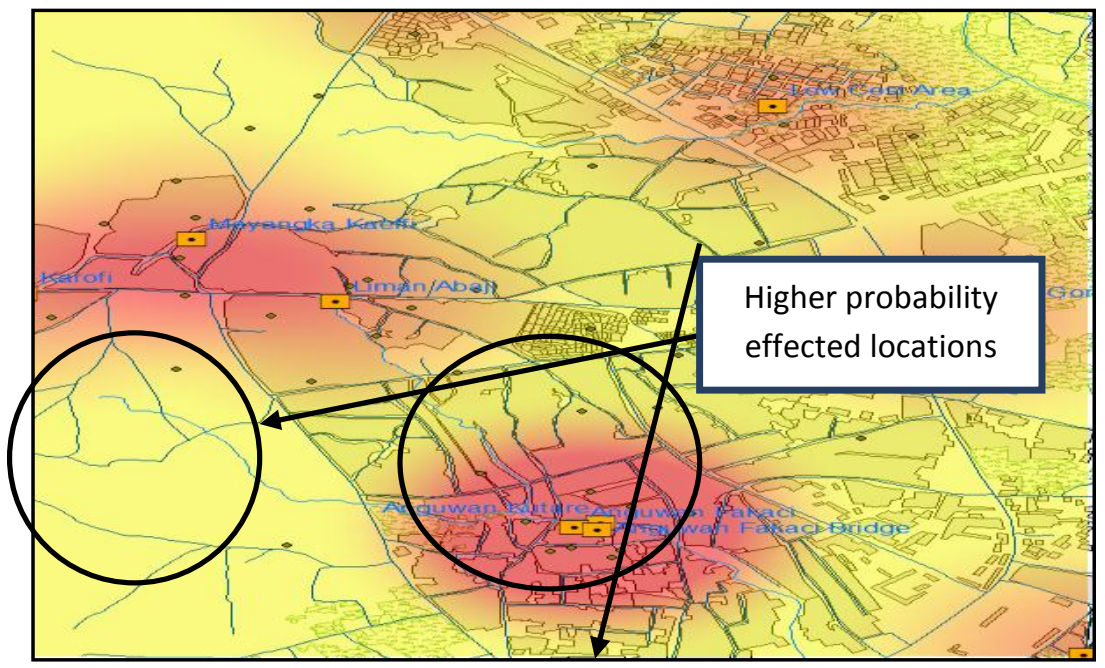

Figure 4.14: Affected areas by the refuse dump site locations in Keffi

From the Figure 4.14 it shows the area that are vulnerable to have infectious diseases from refuse dump sites disposal based on the criteria that taken into account the distance from rivers, roads, vegetation, slope and residential areas.

\section{Conclusion}

There are a lot of benefits derived from the careful study of waste, especially in the developing countries because it made us realize the importance of keeping our environment clean and clear from the dirt. Environmental sustainability is an all-round concern to meet the necessity of modern technology such as GIS to integrate the spatial data into use. This work portrays the complexity in determining the possible solutions to make people cognizant of the effects of living near to the refuse dump sites.

This study put in place various analyses of the role of GIS techniques. There is need to develop a system in the further research in order to broaden the scope of the study to provide refuse dump site's stability in the whole states of the federation. This will assist in minimizing the outbreak of diseases and ill-health condition, environment, social impacts, in the societies.

The application of GIS in selection of suitability and appropriate location of refuse dump sites in Keffi has brought number of lessons; the capability of GIS has displayed results showing all the trends in the geodatabase. Another advantage is the capability of handling bulky data in a repository both spatial and non spatial data. GIS has tools that provide alternative operations especially the role of spatial analyst tools.

People must dispose waste directly or indirectly, for this reason, it is paramount to establish a suitable landfill or dump sites away from the public views. Every portion of the study area will supposed to sustain a specified refuse dump site. The local authority is responsible to check-mate the situation by constant monitoring and planning of each new developed refuse dump site in Keffi. All the 10 existing refuse dump sites location in Keffi are unsuitable. Nevertheless, the local authority must look into the issues to use this analysis to create new strategies using GIS technology to relieve the current trends on solid waste disposal issues. 
Disposal of solid waste will doubled with the influx of people from rural to urban (migration) and subsequent increase in population. Thus the per capita disposal of the refuse dump sites in Keffi will be increased from 0.09 $\mathrm{kg}$ to $1.8 \mathrm{~kg}$. However, there is a need to allocates more new dump sites at regular interval to accommodate the indiscriminate dumping on the roads, streets and vacant and undeveloped lands.

There also needs to prioritize for the involvement of the NGOs to help in investment through cooperating bodies in the state to handle refuse disposal issues since government alone cannot solve the existing problems. It is the communal mode of operation for everyone to insure cleanliness.

The local authority is responsible to deploy more sanitation workers as well as the community health inspectors to every ward in Keffi local government area. This will remedy the situation of disease outbreak. And enlighten the people about the health hazard in the environment. House inspections must be routine health department to make sure no food waste or wastes are recklessly being disposed.

There are needs to establish waste management protocols through the use of private partnership participation (PPP) that will be acceptable to the general public in terms of rapid collection and planning of waste generation and so on.

The acquisition of GIS knowledge and skills became necessary in order to have efficient information retrieval. Most of the information or data are stored digitally in the database. Therefore GIS experts are required in the local authority to handle the tasks.

The use of GIS has proven very effective in analysing the suitability of refuse dump site location in Keffi. In reality, there is need to investigate the situation physically so that the true picture of the analysis can be imaged in the area. The location parameters, the new sites for refuse dump and people involved.

The choice of developmental database has eased the manual method of recording the data concerning solid waste disposal all the worlds. The developed nations have device the ways of sorting refuse and recycle it for economic convenience. Nevertheless, this work is aimed at finding similar technologies for the developing countries such as Nigeria so that new improvement of GIS application can render a lot of achievement toward disposal, collection, generation and suitable placement for new refuse dumps.

\section{Recommendation}

The major challenge facing developing countries especially Nigeria is lack of maintenance culture, whereby people do not consider that our environment needs to be safe and free from diseases. The nonchalant attitude is there that people mostly wait for the government to solve all their needs and problems.

However there is a need to sensitize public on public hygiene and on how to dispose refuse from their household to refuse dump sites in a proper manner. The health inspectors are responsible to manage such situation under ministry of health. The house to house inspection can help in checkmating the reckless disposal. The use of GIS techniques and analysis are so important in determining the suitability index.

The use of media both print and electronics are also paramount so the people should know the danger associated with solid or any kind of waste. We are in a generation that the waste we generate can be easily recycled, reused, reduced and recovered. For planning and decision making the establishment of GIS in every province in Nigeria is required. This will cut down the time and cost of operation and maintenance particularly the development of GIS database for storage, processing, handling and analysis of geospatial data. The ability to use accurate data or information is to be taken when carrying out any GIS analysis.

There is also need for further expansion in the area of research and development to take into cognizance the ever increasing population and manpower development so that the needs assessment will be projected to satisfy the general public. Since we just focused on the selection of suitable dump sites with certain parameters, a global view on this issue probably will be better highlighted for future research such as expand the study area, increase or add other parameters, efficient management of waste disposal, combined techniques and many more.

\section{References:}

[1]. Agamuthu, P. Nather Khan. (1997). Effective solid waste management. Petaling Jaya: Ecotone Management Sdn Bhd

[2]. Bamgbose, J. A. (2009). "Falsification of population census data in a heterogeneous Nigerian state: The fourth republic example." African Journal of Political science and International relations 3(8): 311-319.

[3]. Begum, Rawshan Ara, Siwar, Chamhuri, Pereira, Joy Jacqueline, and Jaafar, Abdul Hamid. (2007). Implementation of waste management and minimisation in the construction industry of Malaysia. Resources, Conservation and Recycling, 51(1), 190-202.

[4]. Gendebien, A, Pauwels, M, Constant, M, Ledrut-Damanet, MJ, Nyns, EJ, Willumsen, HC, and Ferrero, GL. (1992). Landfill gas(from environment to energy). EUR(Luxembourg).

[5]. Grover, Velma I. ( 2000). Solid waste management. Rotterdam : Balkema Publishers.

[6]. Tehobanoglous, George. (1993). Integrated solid waste management : engineering principles and management issues (McGraw-Hill International Edition ed.): New York, NY : McGraw-Hill.

[7]. Yesilnacar, M. I., Süzen, M. L., Kaya, B. S., and Doyuran, V. (2012). Municipal solid waste landfill site selection for the city of Sanliurfa-Turkey: An example using MCDA integrated with GIS. International Journal of Digital Earth, 5(2), 147-164.

[8]. Zerbock, Olar. (2003). Urban Solid Waste Management: Waste Reduction in Developing Nations. (Field Engineering in the Developing World), Master's International Program Michigan Technological University. (CE 5993) 